Federal Reserve Bank of Minneapolis

Research Department Staff Report 240

October 1997

\title{
Government Production of Investment Goods and Aggregate Labor Productivity
}

\author{
James A. Schmitz, Jr.* \\ Federal Reserve Bank of Minneapolis
}

\begin{abstract}
In this paper, I estimate the impact on aggregate labor productivity of having government, rather than private industry, produce investment goods. This policy was pursued to varying degrees by Egypt, India, Turkey, among others. The policy has a large impact because there is both a direct effect (on the production function in the investment sector) and a secondary effect (on the economywide capital stock per worker). I estimate that this policy alone accounted for about one-third of Egypt's aggregate labor productivity gap with the United States during the 1960s.

*The views expressed herein are those of the author and not necessarily those of the Federal Reserve Bank of Minneapolis or the Federal Reserve System.
\end{abstract}




\section{Introduction}

In this paper, I estimate the impact on aggregate labor productivity (ALP) of having government, rather than private industry, produce investment goods. A number of countries have pursued this policy. For long periods, the Egyptian government produced the vast majority of investment goods in that country (and, moreover, most investment spending was spending on domestically produced investment goods - not imports). India and Turkey also pursued this policy, though not as wholeheartedly as Egypt. Interestingly, at its founding, Taiwan started on this path, but then quickly abandoned the policy. I estimate that this single policy alone accounted for about one-third of Egypt's ALP gap with the United States during the 1960 s.

The intuition for why government production of investment goods can have a large negative impact on ALP, even though the investment sector accounts for only about 20 percent

of gross domestic product (GDP), is simple. If government production is less efficient than private production, government production in a sector reduces output and labor productivity. But for the investment sector, this direct effect is only the beginning of the story. If the economy produces investment goods less efficiently, then, all else equal, capital per worker will be smaller in all sectors of the economy. This secondary effect reduces labor productivity in all sectors.

I estimate the impact of this policy using a standard two-sector neoclassical growth model. My only departure from the standard model is to assume that there are two technologies for producing investment goods: a government technology and a private technology. Both technologies exhibit constant returns, with the government's having a lower efficiency (that is, total factor productivity $(\mathrm{TFP})$ ) than the private. Policy is modeled by assuming 
governments impose that a certain fraction of inputs in the investment sector be inputs into the government technology. The final aspect of policy is the setting of taxes on private enterprises and subsidies to government enterprises. Since government TFP is less than private TFP and since both technologies exhibit constant returns, government and private production can exist side by side in competitive equilibrium only if there are taxes on private production or subsidies to government production or a mixture of both. I describe the details of my tax and subsidy scheme below.

Consider the consequences of increasing the government's share of inputs in the investment sector in this version of the neoclassical growth model. First, the policy changes the sector's production function: the policy lowers the sector's TFP (in the model below, the TFP of the investment sector is a weighted average of private and government TFP, with the weights determined by the government's share of inputs). Second, all else equal, the smaller investment-sector TFP lowers the economy's steady-state capital stock. These consequences are the two effects mentioned above: the direct and secondary effects.

A third consequence of increasing the government's share of inputs in the investment sector is that the fraction of inputs devoted to producing investment goods may change. In the two-sector growth model without government production, an exogenous lowering of the investment-sector TFP does not change the fraction of inputs devoted to producing investment goods. But in the modified model, the fall in the investment-sector TFP that follows an increase in the government's share of inputs in the sector changes taxes and subsidies, and this may change the fraction of inputs devoted to producing investment goods. However, for reasons given below, I use a tax and subsidy scheme with the property that increases in the government's share of inputs in the investment sector do not change the fraction of inputs 
devoted to producing investment goods. In this way, I isolate the effects on ALP that result solely from the investment sector being less efficient.

I am able to calibrate each of the model parameters, including the TFP associated with government production and private production in the investment sector. I calculate steady states in the modified model and ask how steady-state ALP depends on the government's share of value added in the investment sector. For example, suppose capital's share of output is one-third and that private producers have TFP twice that of government producers. Then the model estimates that a country with no government production of investment goods has an ALP that is 1.57 times that of a country where investment goods are entirely produced by the government. As shown below, using private TFP that is twice the government's TFP is a conservative estimate. Multiples of 3 or more may be appropriate. If private producers are 3 times as productive, then a country with no government production of investment goods has an ALP twice that of a country where the government produces all investment goods.

Turning to the experience of particular countries, one finds that Egypt aggressively pursued this policy of government production of investment goods for long periods. One such period was the 1960s. For this period, I use the model to answer the question: What fraction of the gap in ALP between the United States, where the government produced no investment goods, and Egypt, where the government accounted for over 75 percent of investment-goods production, was attributable to this policy? During this period, ALP in the United States was about 8 times that of Egypt. As explained in detail below, the model implies that a country with no government production of investment goods will have an ALP that is about twice that of a country like Egypt. So, while the model does not say the United States should be 8 times as productive as Egypt because of this Egyptian policy, the model does say that 
the United States should be twice as productive as Egypt. So, clearly, this single Egyptian policy played an important role in Egypt's productivity gap with the United States. Under one metric, which I discuss below, this policy accounts for one-third of the ALP gap. Briefly, if I had identified three policies, each of which implied that the United States should be twice as productive as Egypt, then, taken together, the policies would imply that the United States should be 8 times as productive as Egypt. Having identified one of three such policies, I am one-third of the way home.

Turning to related literature, one finds that not many papers explore the impact of specific policies on ALP. This fact is not because economists think the issue is an unimportant one, but because of the difficulty of conducting such exercises. The most common type of study in this literature examines the aggregate consequences of trade policy. While the focus of this literature is often the welfare consequences of trade policy, there are studies of trade policy's effects on ALP. Typically, the literature finds that increases in tariffs do not have big effects on welfare or ALP. Recently, some studies find larger effects. Klenow and Rodríguez-Clare (1996) examine a model of a small, open economy with a love-for-variety production function in which increases in tariffs decrease the variety of intermediate goods that are imported and, hence, lower ALP. Rodríguez-Clare (1996) studies a model where, in addition, there are quality upgrades in the intermediate sector. ${ }^{1}$

This paper is also related, but less so, to the recent literature on economic development that constructs models to explain some of the gross features of the cross-country productivity distribution (see the discussion in Lucas (1988)). Some related papers are those by Mankiw,

\footnotetext{
${ }^{1}$ Though I would like to compare my quantitative findings with those of these papers, the findings in these papers are presented in a different manner than my findings. These papers report the percentage decrease in ALP that follows a 10 percent increase in tariffs.
} 
Romer, and Weil (1992); Parente and Prescott (1994); Restuccia and Urrutia (1996); and Chari, Kehoe, and McGrattan (1997). Each of these papers use the neoclassical exogenous growth model (or variants of it) to study the dispersion of ALP. Rather than study the consequences of particular policies for ALP, these papers examine the impact of different savings rates, different costs of adopting improvements to world knowledge, and different relative prices of investment to consumption for ALP. In effect, these papers study the impact of (unspecified) bundles of policies that give rise to different savings rates, different costs of adopting improvements to world knowledge, and different relative prices of investment to consumption for ALP. Of course, the issue of which policies are in these bundles and which have the biggest impact on ALP is important. This issue motivates this paper.

\section{Government Production and Efficiency}

Before presenting the model, let me make some general remarks about the study of government production of goods. I make two points regarding that literature. One point is that most studies that compare private and government productivity take place in the context of industries such as electricity, communications, and transportation, which are industries that have some aspects of natural monopoly. These industries have typically been organized in one of two ways: as a government-owned and government-managed industry or as a privately owned monopoly that is strictly regulated by government. Which option provides greater efficiency? While experience perhaps indicates that the private, regulated option does provide greater efficiency, some studies show the opposite as well. And in any case, the differences in productivity are typically not staggering.

But these studies are not relevant for my analysis. The industries that comprise the 
investment sector (for example, cement, construction, machine tools, chemicals, and steel) are not natural monopolies. Hence, though they are often organized as government monopolies in some countries (for example, in Egypt, India, and Turkey), in many other countries (for example, in the United States), these industries have a competitive market structure with many producers and free entry. Hence, for my analysis, I choose studies that compare the productivity of investment-good industries when they are government owned and managed versus when they are structured competitively.

Some productivity studies make such comparisons. I describe these studies in the calibration section. For now, let me simply say that, in contrast to the studies that compare government and private TFP in the electricity and like industries, studies of investment-good industries find that private TFP and government TFP are significantly different, with private TFP typically being 2 and 3 times that of government TFP.

The other point about the study of government production concerns the literature that studies the aggregate consequences of government production. This literature typically does not distinguish between the type of good - consumption or investment-that governments produce. Rather, the literature simply focuses on the government's share of total output. For example, this is true of the World Bank's (1995) recent study of government enterprise. But because government production of investment goods has both direct and secondary effects, while government production of consumption goods has only a direct effect, the types of goods the government produces matter for determining the aggregate impact of its production.

To show this, I use the calibrated model to compare a policy in which government produces only investment goods to a policy in which government produces only consumption goods (and in which government accounts for the same fraction of total inputs under both 
policies). Suppose government accounts for 20 percent of total inputs under both policies (so that government accounts for the entire investment sector, which is calibrated to account for 20 percent of inputs). From the example discussed above, one knows that if private TFP is 3 times that of government TFP, then a country with no government production of investment goods has an ALP twice that of a country where the government produces all investment goods. In contrast, a country with no government production has an ALP that is only 1.15 times that of a country where the government produces only consumption goods. So government production of consumption goods has a small effect on ALP, peanuts really.

Let me conclude the section by making two comments about the applicability of my approach. First, the model below examines the consequences of a government policy that reduces productivity in the investment sector. Governments pursue many policies that have this effect: government production of investment goods, greater restrictions on entry into industries in this sector, and regulations on production methods, to name a few. I focus on government production because it is relatively easy to analyze this policy. In particular, I find it easy to measure the extent to which government pursues this policy (measured by using government value added) and the effects of the policy on TFP (measured by using productivity studies). But it may be possible to evaluate the ALP consequences of these other policies by using the approach below. For example, the TFP consequences of certain regulations are measured.

The second comment is that I have only obtained detailed data on government production of investment goods for a few countries. However, evidence presented in Schmitz (1996) on the government's share of manufacturing output suggests that a much larger group of countries have pursued this policy than the small group I have, thus far, assembled data 
for. $^{2}$

The remainder of the paper proceeds as follows. The model is presented in the next section. I then give the steady-state equilibrium and relative productivity formulas for the model. I then calibrate the parameters that are needed to evaluate relative productivity. The model's estimate for the impact of this policy is then given. The comparison of a policy in which government produces only investment goods to one in which it produces only consumption goods is given next. I then give some concluding comments.

\section{Model}

I begin with a standard two-sector exogenous growth model. I then describe my modifications. In the model, there is a representative individual, and population is normalized to 1 . The individual has preferences given by

$$
\sum_{t=0}^{\infty} \beta^{t} \cdot \frac{c_{t}^{1-\theta}-1}{1-\theta}
$$

where $c_{t}$ is total consumption (and consumption per capita since population is 1) at date $t$, $\beta$ is the discount factor, and $\theta \geq 0$. The household is endowed with $k_{0}$ units of capital at $t=0$ and 1 unit of time at each date.

Let $s$ index sector, with $s=c$ denoting the consumption sector, $s=x$ the investment sector. The technology for producing good $s$ is

$$
\mu \cdot f_{s t}\left(k_{s t}, n_{s t}\right)=\mu \cdot A_{s} \cdot k_{s t}^{\gamma} \cdot\left((1+g)^{t} \cdot n_{s t}\right)^{1-\gamma}
$$

where $\left(k_{s t}, n_{s t}\right)$ are the units of capital and time, respectively, devoted to the production of good $s$, and $g$ is the exogenous rate of technological change. Each sector has the same

\footnotetext{
${ }^{2}$ The relationship between the government's share of investment output and its share of manufacturing output is discussed below.
} 
production function except for its TFP; namely, $\mu \cdot A_{s}$.

The total capital stock $k_{t}$ and time input $n_{t}$ satisfy $k_{t}=k_{c t}+k_{x t}$ and $n_{t}=n_{c t}+n_{x t}=1$. The law of motion for capital is the usual one. That is, if $x_{t}$ denotes investment goods produced at date $t$, then next period's capital satisfies $k_{t+1}=(1-\delta) \cdot k_{t}+x_{t}$.

I make only slight modifications to this standard model. I assume that if there is government production in a sector, then the government uses the technology in (1), but with TFP equal to $\mu_{g} \cdot A_{s}$ ( $g$ for government). I also assume that the presence of government may change the technology of private producers (if any remain). I assume that with government production, private producers employ the technology in $(1)$, but with TFP equal to $\mu_{p} \cdot A_{s}$ ( $p$ for private).

For example, consider the investment sector. Let $x_{t}^{g}$ and $x_{t}^{p}$ denote the output of investment goods from the government and private technology, respectively. Government production obeys

$$
x_{t}^{g}=\mu_{g} \cdot f_{x t}\left(k_{x t}^{g}, n_{x t}^{g}\right)
$$

where $\left(k_{x t}^{g}, n_{x t}^{g}\right)$ are the inputs of capital and time to the government technology for producing investment goods. Hence, the government technology is simply $f_{x t}(\cdot, \cdot)$ multiplied by $\mu_{g}$, rather than $\mu$. With government production, private production obeys

$$
x_{t}^{p}=\mu_{p} \cdot f_{x t}\left(k_{x t}^{p}, n_{x t}^{p}\right)
$$

where $\left(k_{x t}^{p}, n_{x t}^{p}\right)$ are the inputs of capital and time to the private technology for producing investment goods. The private technology is simply $f_{x t}(\cdot, \cdot)$ multiplied by $\mu_{p}$, rather than $\mu$.

I do not expect small amounts of government production to influence private production, so the technology in (3) is understood to hold when government accounts for a large 
share of sectoral inputs. By large shares of inputs I mean, say, 50 percent and greater.

Total investment $x_{t}$ equals $x_{t}^{g}+x_{t}^{p}$. Also, note that the inputs to the two investment technologies must satisfy $k_{x t}^{g}+k_{x t}^{p} \leq k_{x t}$ and $n_{x t}^{g}+n_{x t}^{p} \leq n_{x t}$.

I treat the consumption sector in an identical manner to the investment sector. In particular, $c_{t}^{g}$ and $c_{t}^{p}$ denote the output of consumption goods from the government and private technology, respectively. Again, whereas the original technology is $\mu \cdot f_{c t}(\cdot, \cdot)$, the two technologies when there is government production are $\mu_{g} \cdot f_{c t}(\cdot, \cdot)$ and $\mu_{p} \cdot f_{c t}(\cdot, \cdot)$. Total consumption $c_{t}$ equals $c_{t}^{g}+c_{t}^{p}$, while the inputs to the two technologies must satisfy $k_{c t}^{g}+k_{c t}^{p} \leq$ $k_{c t}$ and $n_{c t}^{g}+n_{c t}^{p} \leq n_{c t}$.

\section{Competitive Equilibrium}

Before formally defining a competitive equilibrium, let me discuss how I model government policy. I assume that the government imposes a requirement that inputs into the government technology in sector $s$ equal a fraction $\lambda_{s}$ of total inputs in that sector (of both time and capital). That is, the government requires that

$$
\frac{k_{s t}^{g}}{k_{s t}}=\lambda_{s} \quad \text { and } \quad \frac{n_{s t}^{g}}{n_{s t}}=\lambda_{s}
$$

where, again, $\left(k_{s t}^{g}, n_{s t}^{g}\right)$ are the inputs of capital and time to the government technology and $\left(k_{s t}, n_{s t}\right)$ are the total inputs in sector $s$. As in the actual world, governments in the model choose different $\lambda_{s}$ 's. Presumably, a government chooses to employ inefficient enterprises because the enterprises offer other benefits, like providing jobs to political supporters. I will not model how these $\lambda_{s}$ choices are determined. Rather, I explore how these choices impact ALP. 
Since government TFP is less than private TFP and since both technologies exhibit constant returns, government and private production can exist side by side in competitive equilibrium only if there are taxes on private production or subsidies to government production or a mixture of both. The scheme I use is to give government producers in a sector a subsidy that is tied to their revenues that is paid for by a tax on the revenue of private producers in the same sector. I discuss the reasons for choosing this scheme below.

\section{A. Definition of Equilibrium}

The representative individual owns both the capital stock and the unit of time. The individual rents both to firms in the economy. There are four representative firms in the economy (which are also owned by the individual). There are two firms in each sector: a private enterprise (which uses the private technology) and a government enterprise (which uses the government technology). Government enterprises receive a subsidy that is a percentage of their sales. The subsidies are financed with a tax on private enterprises in the same sector that is a percentage of their sales.

Let the consumption good be the numeraire, and let $p_{x t}$ denote the date $t$ price of the investment good in units of the consumption good. Let $w_{t}$ and $r_{t}$ be the date $t$ rental rates of time and capital in units of the consumption good. Then I can write the decision problems of the household and enterprises as follows:

\section{Household's Problem:}

The household's problem is straightforward: given a sequence $\left(p_{x t}, w_{t}, r_{t}\right)$, choose a sequence $\left(c_{t}, x_{t}\right)$ to maximize the discounted sum of utility subject to the budget constraint in each period: $c_{t}+p_{x t} \cdot x_{t} \leq w_{t}+r_{t} \cdot k_{t}$, the law of motion for capital, and the endowment 
of capital $k_{0} \cdot{ }^{3}$

Private Enterprise's Problem (in sector s):

The private enterprise chooses $\left(k_{s}^{p}, n_{s}^{p}\right)$ to maximize

$$
\left(1-\tau_{s}\right) \cdot p_{s} \cdot \mu_{p} \cdot f_{s t}\left(k_{s}^{p}, n_{s}^{p}\right)-w \cdot n_{s}^{p}-r \cdot k_{s}^{p}
$$

where $\tau_{s}$ is the percentage tax (in consumption-good units) on the sales of private enterprises and $p_{c}=1$.

Government Enterprise's Problem (in sector s):

The government enterprise chooses $\left(k_{s}^{g}, n_{s}^{g}\right)$ to maximize

$$
\left(1+\sigma_{s}\right) \cdot p_{s} \cdot \mu_{g} \cdot f_{s t}\left(k_{s}^{g}, n_{s}^{g}\right)-w \cdot n_{s}^{g}-r \cdot k_{s}^{g}
$$

where $\sigma_{s}$ is the percentage subsidy on the sales of government enterprises.

I define equilibrium as follows. An equilibrium given $\left(\lambda_{c}, \lambda_{x}\right)$ is a list of prices $\left(p_{x t}, w_{t}, r_{t}\right)$, choices for the household $\left(c_{t}, x_{t}\right)$, choices for the private enterprises $\left(k_{s t}^{p}, n_{s t}^{p}\right)$, choices for the government enterprises $\left(k_{s t}^{g}, n_{s t}^{g}\right)$, and a subsidy-tax pair $\left(\sigma_{s}, \tau_{s}\right)$ that satisfy utility maximization; profit maximization; market clearing for capital, time, and goods; in sector $s$, subsidies equal to taxes; and in sector $s$, the government-enterprise share of time and capital inputs equal to $\lambda_{s}$.

A steady state is a list of sequences

- $\left(p_{x t}, w_{t}, r_{t}\right)=\left(p_{x}^{*}, w^{*} \cdot(1+g)^{t}, r^{*}\right)$

- $\left(c_{t}, x_{t}\right)=\left(c^{*} \cdot(1+g)^{t}, x^{*} \cdot(1+g)^{t}\right)$

- $\left(k_{s t}^{p}, n_{s t}^{p}\right)=\left(\left(k_{s}^{p}\right)^{*} \cdot(1+g)^{t},\left(n_{s}^{p}\right)^{*}\right)$ for $s=c, x$

\footnotetext{
${ }^{3}$ Note that I use $n_{t}=1$ in the household's problem.
} 
- $\left(k_{s t}^{g}, n_{s t}^{g}\right)=\left(\left(k_{s}^{g}\right)^{*} \cdot(1+g)^{t},\left(n_{s}^{g}\right)^{*}\right)$ for $s=c, x$ and

- $\left(\sigma_{s}, \tau_{s}\right)=\left(\sigma_{s}^{*}, \tau_{s}^{*}\right)$

that satisfy the equilibrium conditions above. Along the steady state, both $k_{s t}$ and $k_{t}$ grow at rate $g$, with $k_{s t}=k_{s}^{*} \cdot(1+g)^{t}$, where $k_{s}^{*}=\left(k_{s}^{p}\right)^{*}+\left(k_{s}^{g}\right)^{*}$, and $k_{t}=k^{*} \cdot(1+g)^{t}$, where $k^{*}=k_{c}^{*}+k_{x}^{*}$.

\section{B. Steady-State Solution}

In this section, I present the steady-state paths for $x_{t}, c_{t}$, and $p_{x t}$ (see the Appendix for the calculations). These paths allow me to calculate ALP in the next section.

I introduce some notation. Let $m_{s}\left(\lambda_{s}\right)$ be defined as

$$
m_{s}\left(\lambda_{s}\right)=\left\{\begin{array}{lr}
\mu & \text { if } \lambda_{s}=0 \\
\bar{\mu}_{s} & \text { if } \lambda_{s} \text { is large }
\end{array},\right.
$$

where $\bar{\mu}_{s}=\left(\lambda_{s} \cdot \mu_{g}+\left(1-\lambda_{s}\right) \cdot \mu_{p}\right)$; that is, $\bar{\mu}_{s}$ is a weighted average of the government and private TFP parameters $\mu_{g}$ and $\mu_{p}$ (where the weights are the government and private share of inputs in sector $s$ ) and where $\lambda_{s}$ large means $\lambda_{s}$ greater than 0.5 .

The path for $x_{t}$ is

$$
x_{t}=(1+g)^{t} \cdot m_{x}\left(\lambda_{x}\right) \cdot A_{x} \cdot\left(k^{*}\right)^{\gamma} \cdot \frac{k_{x}^{*}}{k^{*}},
$$

where the solutions for $k^{*}$ and $k_{x}^{*} / k^{*}$ are given below. The term $k^{*}$ is capital per person divided by $(1+g)^{t}$ (or capital per effective person), and $k_{x}^{*} / k^{*}$ is the fraction of the capital stock devoted to producing investment goods (which also equals the fraction of time devoted to the investment sector). The consumption path is

$$
c_{t}=(1+g)^{t} \cdot m_{c}\left(\lambda_{c}\right) \cdot A_{c} \cdot\left(k^{*}\right)^{\gamma} \cdot\left(1-\frac{k_{x}^{*}}{k^{*}}\right) .
$$


The solution for $k_{x}^{*} / k^{*}$ is

$$
\frac{k_{x}^{*}}{k^{*}}=\beta \cdot \gamma \cdot \frac{(1+g)-(1-\delta)}{(1+g)^{\theta}-\beta \cdot(1-\delta)},
$$

while that for $k^{*}$ is

$$
k^{*}=\left[\frac{\beta \cdot \gamma \cdot m_{x}\left(\lambda_{x}\right) \cdot A_{x}}{(1+g)^{\theta}-\beta \cdot(1-\delta)}\right]^{\frac{1}{1-\gamma}} .
$$

Finally, the steady-state relative price of investment is

$$
p_{x}^{*}=\frac{m_{c}\left(\lambda_{c}\right)}{m_{x}\left(\lambda_{x}\right)} \cdot \frac{A_{c}}{A_{x}}
$$

Let me briefly discuss the steady-state solution. If there is no government production, that is, $\lambda_{c}=\lambda_{x}=0$, then, from expression (4), $m_{c}\left(\lambda_{c}\right)=m_{x}\left(\lambda_{x}\right)=\mu$ in the expressions above. If the government produces investment goods, that is, if $\lambda_{x}$ is large (and $\lambda_{c}=0$ ), then $m_{c}\left(\lambda_{c}\right)=\mu$ and $m_{x}\left(\lambda_{x}\right)=\bar{\mu}_{x}$ in the expressions above. Examining expressions (5), (6), (7), (8), and (9), one finds that increases in $\lambda_{x}$ have the same qualitative influences on the steady state as decreases in $A_{x}$. An increase in $\lambda_{x}$ or a reduction in $A_{x}$ have the following effects: they lower the $x_{t}$ path in (5); they do not influence the fraction of the capital stock devoted to producing investment goods $k_{x}^{*} / k^{*}$ in $(7)$; they lower $k^{*}$, that is, the total capital stock divided by $(1+g)^{t}$, in $(8)$; and they increase the relative price of investment goods in $(9)$.

I choose the tax and subsidy scheme above precisely because under the scheme, increases in $\lambda_{x}$ have the same qualitative influence as reductions in $A_{x}$ in the case of no government production. Hence, the policy's influence on ALP stems directly from its making the investment sector less productive. Some financing schemes decrease the fraction of the capital stock that is devoted to the investment sector and, hence, lead to a bigger decrease in productivity than the scheme above. And other schemes lead to an increase in the fraction of 
the capital stock that is devoted to the investment sector and, hence, a smaller productivity decrease. I thought it best to remain agnostic about how financing issues impact $k_{x}^{*} / k^{*}$ and so choose the scheme above. In the Appendix, I briefly discuss some other financing schemes. ${ }^{4}$

\section{Relative Productivity Formulas}

In this section, I calculate productivity formulas. In the next section, I calibrate the parameters in the formulas.

Index countries by $i \in\{E, U\}, E$ for Egypt and $U$ for the United States. Then I assume that $\lambda_{U s}=0$ for $s=c, x$. Also, let $\lambda_{E c}=\lambda_{c}$ and $\lambda_{E x}=\lambda_{x}$ and assume both are large. For simplicity, I drop the E subscript on the $\lambda$ 's for Egypt since for the United States, the $\lambda$ 's are taken to be 0 .

Let me start by comparing sectoral labor productivity in the steady state. Consider the investment sector. Labor productivity in this sector in country $i$ is $x_{i} / n_{i x}$, where $x_{i}$ is from (5) and $n_{i x}=k_{i x} / k_{i}$ is from (7) (and note that $n_{i x}$ does not depend on $i$ ). Labor productivity in the United States relative to Egypt is

$$
\frac{x_{U} / n_{U x}}{x_{E} / n_{E x}}=\frac{x_{U}}{x_{E}}=\frac{m_{U x}\left(\lambda_{U x}\right) \cdot A_{x}}{m_{E x}\left(\lambda_{E x}\right) \cdot A_{x}} \cdot \frac{\left(k_{U}^{*}\right)^{\gamma}}{\left(k_{E}^{*}\right)^{\gamma}}=\frac{\mu}{\bar{\mu}_{x}} \cdot\left(\frac{\mu}{\bar{\mu}_{x}}\right)^{\frac{\gamma}{1-\gamma}}
$$

where, from (4), $m_{U x}\left(\lambda_{U x}=0\right)=\mu$ and $m_{E x}\left(\lambda_{E x}=\lambda_{x}\right)=\bar{\mu}_{x}$. The term $\mu / \bar{\mu}_{x}$ is the investment-sector TFP of a country with no government production of investment goods relative to the investment-sector $\mathrm{TFP}$ of a country where the government does produce

\footnotetext{
${ }^{4}$ One way to avoid the issue of how to subsidize government production and tax private production is to assume that $\lambda_{x}=1$. In this case, the only enterprises in the investment sector are government enterprises, so they incur no losses. The advantage of making this assumption is that the model can then be described much more succinctly. The disadvantages are that it is an approximation since no country has $\lambda_{x}=1$ (though for Egypt, the approximation is not too bad), and I am then not able to compare the impact on ALP of a policy in which the government produces investment goods versus one in which it produces consumption goods (since the government necessarily will account for only a fraction of the consumption sector).
} 
investment goods. Formula (10) shows two effects of substituting government for private production. The first term in formula (10) corresponds to the direct effect: the production function changes. The second term corresponds to the secondary effect: capital per worker falls.

Relative labor productivity in the consumption-good sector equals

$$
\frac{c_{U} / n_{U c}}{c_{E} / n_{E c}}=\frac{c_{U}}{c_{E}}=\frac{m_{U c}\left(\lambda_{U c}\right) \cdot A_{c}}{m_{E c}\left(\lambda_{E c}\right) \cdot A_{c}} \cdot \frac{\left(k_{U}^{*}\right)^{\gamma}}{\left(k_{E}^{*}\right)^{\gamma}}=\frac{\mu}{\bar{\mu}_{c}} \cdot\left(\frac{\mu}{\bar{\mu}_{x}}\right)^{\frac{\gamma}{1-\gamma}} .
$$

Note that government production of investment influences relative productivity in this sector because it means capital per worker is smaller in the sector.

Next I compare the ALP of the two countries. In such comparisons, it is typical practice to use a common set of prices to value goods. Let $\widehat{p}$ denote such a common investment price. Let $z(\widehat{p})$ denote relative ALP when the price $\widehat{p}$ is used to value output in both countries; that is, $z(\widehat{p})=y_{U}(\widehat{p}) / y_{E}(\widehat{p})$, where $y_{i}(\widehat{p})=c_{i}+\widehat{p} \cdot x_{i}$. It is easy to show that $z(\widehat{p})$ can be expressed as

$$
z(\widehat{p})=\omega_{c}(\widehat{p}) \cdot \frac{c_{U}}{c_{E}}+\omega_{x}(\widehat{p}) \cdot \frac{x_{U}}{x_{E}},
$$

where

$$
\omega_{c}(\widehat{p})=\frac{c_{E}}{c_{E}+\widehat{p} \cdot x_{E}}=\left(1+\widehat{p} \cdot \frac{x_{E}}{c_{E}}\right)^{-1}=\left(1+\widehat{p} \cdot \frac{\bar{\mu}_{x} A_{x} n_{x}^{*}}{\bar{\mu}_{c} A_{c} n_{c}^{*}}\right)^{-1}
$$

and where $\omega_{x}(\widehat{p})=1-\omega_{c}(\widehat{p})$.

Next I evaluate the weight $\omega_{c}(\widehat{p})$. First, I choose an international price $\widehat{p}$. I use country $U$ 's price as the international price; that is, $\widehat{p}=p_{U}=A_{c} / A_{x}$. I use country $U$ 's price as the international price because it is simple and, importantly, because the decrease in country E's productivity as a result of government production will be smaller by using country $U$ 's price 
than by using a price that is some average of country $U$ 's and E's price. Hence, by using country U's price, I do not bias the results toward bigger decreases in measured productivity. ${ }^{5}$

Second, $n_{x}^{*}$ and $n_{c}^{*}$ depend on the parameters $\beta, \delta, \theta, g$, and $\gamma$. For these parameters, I use $\beta=0.96, \delta=0.04, \theta=1, g=0.025$, and $\gamma=1 / 3$. With these parameters, $n_{x}^{*}=0.20$ and $n_{c}^{*}=0.80$. So the fraction of time devoted to the investment sector (which in the model also equals the investment sector's share of GDP in local prices) equals 20 percent. With these two conventions, I have

$$
\omega_{c}(\widehat{p})=\left(1+\frac{1}{4} \cdot \frac{\bar{\mu}_{x}}{\bar{\mu}_{c}}\right)^{-1}
$$

In summary, to estimate the impact of government production of consumption and investment goods on productivity, one uses the relative sectoral productivity formulas (10) and (11), together with the weight (13), to calculate $z$ in (12).

To determine the productivity consequences of a policy in which the government produces only investment goods, use $m_{E c}\left(\lambda_{E_{c}}=0\right)=\mu$ and $m_{E x}\left(\lambda_{E x}=\lambda_{x}\right)=\bar{\mu}_{x}$ in formula (12). The expression for $z$ then becomes (where remember that $\gamma=1 / 3$ )

$$
z=\left(1+\frac{1}{4} \cdot \frac{\bar{\mu}_{x}}{\mu}\right)^{-1} \cdot\left(\frac{\mu}{\bar{\mu}_{x}}\right)^{\frac{1}{2}}+\left[1-\left(1+\frac{1}{4} \cdot \frac{\bar{\mu}_{x}}{\mu}\right)^{-1}\right] \cdot\left(\frac{\mu}{\bar{\mu}_{x}}\right)^{\frac{3}{2}}
$$

The parameters determining $z$ in this case are $\lambda_{x}, \mu / \mu_{g}$, and $\mu / \mu_{p}$.

\footnotetext{
${ }^{5}$ To see the last claim, note that

$$
\omega_{c}\left(\widehat{p}=p_{U}\right)=\left(1+\frac{\bar{\mu}_{x} n_{x}^{*}}{\bar{\mu}_{c} n_{c}^{*}}\right)^{-1}>\omega_{c}\left(\widehat{p}=p_{E}\right)=\left(1+\frac{n_{x}^{*}}{n_{c}^{*}}\right)^{-1}
$$

as long as $\bar{\mu}_{x}<\bar{\mu}_{c}$. Hence, as long as the inequality holds, the price system $p_{U}$ puts greater weight on $c_{U} / c_{E}$ than does the price system $p_{E}$. Price system $p_{E}$, therefore, puts greater weight on $x_{U} / x_{E}$. Now, when I study the impact of government production of investment goods, this inequality is satisfied. Also, the policy leads to a greater reduction of productivity in the investment sector than the consumption sector; that is, $x_{U} / x_{E}>c_{U} / c_{E}$. Hence, since $p_{E}$ puts greater weight on $x_{U} / x_{E}, U$ 's productivity advantage over $E$ will be greater under the price system $p_{E}$ than under $p_{U}$. If instead of using price system $p_{E}$, I use some average of the two price systems, a similar finding would emerge. In this sense, by using $p_{U}$, I provide a lower bound to the measured productivity decrease from the policy.
} 


\section{Calibration}

In order to evaluate the relative productivity formula in (14), I need to specify the parameters $\lambda_{x}, \mu / \mu_{g}$, and $\mu / \mu_{p}$. I discuss each parameter in turn.

Government Involvement in the Investment Sector (that is, $\lambda_{x}$ ).

Though many governments play large roles in their respective investment sectors, it is difficult to obtain the disaggregated data that are needed to quantify the extent of production. For example, India is a country where the government has played an important role in producing investment goods, but for which I have not found detailed data. According to Srinivasan (1993), the Indian government played a large role in India's "heavy-industry development strategy." As he describes, the idea was to keep

the cost of capital goods as low as possible, particularly equipment that is at the farthest end from final consumption goods. If the government had complete control over this industry, it would be able to control prices and shape the pattern of industrialization. And by regulating imports, it could also influence investment in the private sector. As it turned out, however, domestic production of equipment by the public sector, price controls, and the restriction of competition from imports raised rather than lowered the cost of this equipment. (p. 104)

Despite data availability problems, I have collected reasonable amounts of data for three countries: Egypt, Taiwan, and Turkey. The governments of Egypt and Turkey played large roles in their respective investment sectors for extended periods. In Taiwan, the government also played a large role, but for a very brief period. I include Taiwan, then, not to show how this policy reduced productivity in the country, but as an example of a country 
that could have followed this path but did not. Interestingly, it seems that a major reason Taiwan dropped this policy was due to pressure from the United States during the Korean War (see Schmitz (1996)).

I start by examining the government's share of domestic production of investment goods in Egypt, Taiwan, and Turkey. I then consider the extent of investment-good imports in these countries.

Investment goods consist of equipment and structures. Investment goods are produced in two sectors of the economy: the manufacturing sector and the construction sector. The manufacturing sector produces intermediate goods (for example, cement and steel) that are used in producing equipment and structures. The manufacturing sector also produces equipment. The construction sector produces structures by using intermediate goods (for example, cement). In symbols,

$$
\begin{aligned}
x & =x_{\text {man }}+x_{c o n} \\
& =\left(x_{i n t}+x_{e q p}\right)+x_{c o n},
\end{aligned}
$$

where $x$ is total production of investment goods, and $x_{m a n}$ and $x_{c o n}$ denote the production of investment goods in the manufacturing and construction sectors; $x_{\text {man }}$ can then be divided into the value of intermediate goods that are produced in the manufacturing sector (that are used in producing equipment and structures), which I denote as $x_{i n t}$ and equipment value added, which I denote as $x_{e q p}$.

The government's share of domestic production of investment goods can be expressed as a weighted average of the government's share of investment goods produced in the manu- 
facturing and construction sectors; namely,

$$
\frac{x^{g}}{x}=\frac{x_{m a n}}{x} \cdot \frac{x_{m a n}^{g}}{x_{m a n}}+\frac{x_{c o n}}{x} \cdot \frac{x_{c o n}^{g}}{x_{c o n}}
$$

where a $g$ superscript denotes government production. ${ }^{6}$

I now consider the value of $x_{\text {man }}^{g} / x_{\text {man }}$ in Egypt, Taiwan, and Turkey. Table 1 gives the government's share of value added in the intermediate-goods industries and equipment industries in these countries. That is, Table 1 gives $x_{i n t}^{g} / x_{i n t}$ and $x_{e q p}^{g} / x_{e q p}$. For Egypt and Turkey, the data are for the years 1966-67 and 1968, respectively. These years are dictated somewhat by data availability, but they are years that are in the middle of long periods of government involvement in the sector and give, I think, a fairly representative picture of the extent of this involvement. For Taiwan, I choose a year shortly after the country's founding. After the early 1950s, the government quickly retreated from the industries listed on Table 1.

As one can see, the governments in Egypt, Taiwan, and Turkey produced a large share of the output in many of the industries listed on Table 1. Government involvement in Egypt was greater than in the other two countries. In particular, for each industry, the government's share of value added was greatest in Egypt, with shares of 90 percent or more common. The weighted-average share of government production was 81.9 percent; that is, $x_{\text {man }}^{g} / x_{\text {man }}=0.819$. While government involvement in these industries in the other two countries was not as great as Egypt's, government involvement was significant nonetheless:

\footnotetext{
${ }^{6}$ Let me say a few words about definitions. I call the enterprises that are owned by the government government enterprises. In practice, a distinction is made between two types of government-owned enterprises: those that sell their output are typically called public enterprises, and those that do not sell their output are typically called government enterprises. In the manufacturing sector, government production typically occurs only in public enterprises; in the construction sector, government production may occur in both enterprises. Value added in government enterprises is measured by the wages of employees.
} 
the weighted-average share was 61.2 and 40.7 percent in Turkey and Taiwan, respectively. ${ }^{7}$

Next I consider the government's share of construction value added, $x_{c o n}^{g} / x_{c o n}$. Unfortunately, it is more difficult to obtain data on government value added for this industry than for the manufacturing industries. But for the construction industry, it appears that government involvement in Egypt is, again, greater than in the other two countries. According to Waterbury (1993, p. 93), who cites a World Bank study, government production accounted for 75 percent of construction value added in Egypt; that is, $x_{c o n}^{g} / x_{c o n}=0.75$. I do not have an estimate for Turkey.

I now calculate $x^{g} / x$ in (15). Again, for Egypt, $x_{\text {man }}^{g} / x_{m a n}=0.819$ and $x_{\text {con }}^{g} / x_{\text {con }}=$ 0.75. For Egypt for this period, $x_{\text {man }} / x=0.575$ and $x_{\text {con }} / x=0.425$ (see Mabro and Radwan (1976)). Hence, for Egypt, $x^{g} / x=0.79$. In Egypt, therefore, the government accounted for a very large share of domestic production of investment goods. Again, for Turkey, $x_{\text {man }}^{g} / x_{\text {man }}=$ 0.612, though recall that I do not have an estimate for $x_{c o n}^{g} / x_{c o n}$. For Turkey for this period, $x_{m a n} / x=0.455$ and $x_{c o n} / x=0.545$ (see Walstedt $(1980)$ ).

Next I consider the imports of investment goods. During the 1950s and 1960s (and beyond), many countries, including Egypt and Turkey, followed import-substitution policies in manufacturing. These policies most often targeted the manufacture of consumption goods (for example, textiles, food processing, and so on), but frequently, the policies included intermediate goods and equipment as well (as the policies did in Egypt and Turkey). As a result, as I now argue, imports did not play a big role in investment spending in Egypt and

\footnotetext{
${ }^{7}$ I have two remarks about Table 1 . First, some intermediate goods produced in the manufacturing sector are used to produce consumer durables, while some intermediate goods are used to produce some investment goods. I do not have the government's share of output in intermediate goods produced for consumer durables and intermediate goods produced for investment goods. I assume the government's share is the same in both. Second, the estimates for Turkey from Walstedt (1980) are based on establishments employing 10 or more.
} 
Turkey.

Let $\widetilde{x}$ denote total spending on investment goods. Total investment spending equals domestic production plus the value of imports, or

$$
\begin{aligned}
\tilde{x} & =x+x_{i m p} \\
& =x+\left(x_{i m p, i n t}+x_{i m p, e q p}\right),
\end{aligned}
$$

where $x_{i m p}$ denotes the value of imports, and $x_{i m p, i n t}$ and $x_{i m p, e q p}$ denote the imports of intermediate and equipment goods, respectively. ${ }^{8}$

Table 2 lists domestic production of investment goods and imports of investment goods as a share of total investment spending (that is, $x / \widetilde{x}$ and $x_{i m p} / \widetilde{x}$ ). Table 2 also presents imports by type of good (intermediate or equipment) and imports' share of investment spending (that is, $x_{i m p, i n t} / \widetilde{x}$ and $x_{i m p, e q p} / \widetilde{x}$ ). The estimates for Turkey are obtained from Krueger (1974). During 1958, domestic production accounted for 77 percent of investment spending in Turkey; imports amounted to 23 percent. So imports of investment goods made up a minor share of investment spending in Turkey during $1958 .{ }^{9}$ I derive the estimates for Egypt from information in Hansen and Nashashibi (1975). During 1966-67, domestic production accounted for 80 percent of investment spending, and imports amounted to 20 percent. In this country, too, imports of investment goods made up a minor share of investment spending

\footnotetext{
${ }^{8}$ For these countries, during the periods I study, exports of investment goods were very small and, hence, are not included in the spending identity.

${ }^{9}$ The information for 1958 is derived from Krueger (1974, p. 111, Table IV-9). Table IV-9 includes information for the years 1957-60. During these four years, imports accounted for 25, 23, 33, and 34 percent of total investment spending, respectively. The domestically produced share of total investment spending was, therefore, $75,77,67$, and 66 percent, respectively. I now make a final point about the Turkish data. I use statistics for the late 1950s in Table 2 for Turkey, even though the statistics in Table 1 for Turkey are from 1968, because calculating numbers such as those in Table 2 is difficult. Hence, I prefer to use a source which compiles these numbers (though for a slightly different period), rather than estimate them myself.
} 
during this period.

That imports made up a small fraction of investment spending in Egypt and Turkey during these periods may surprise some readers. In order to better understand this fact, let me discuss this issue further. Let me focus on Turkey since the data in Krueger (1974) allow a detailed analysis of this issue. I discuss data for 1958. I express the share of imports to total spending as

$$
\frac{x_{i m p}}{\widetilde{x}}=\frac{\widetilde{x}_{e q p}}{\widetilde{x}} \cdot \frac{x_{i m p, e q p}}{\widetilde{x}_{e q p}}+\frac{\widetilde{x}_{c o n}}{\widetilde{x}} \cdot \frac{x_{i m p, i n t}}{\widetilde{x}_{c o n}},
$$

where $\widetilde{x}_{e q p}$ denotes spending on equipment and $\widetilde{x}_{c o n}$ denotes spending on construction. Again, for $1958, x_{i m p} / \widetilde{x}=0.23$. Imports of equipment did make up a large share of spending on equipment in Turkey in 1958, namely, 67 percent. That is, $x_{i m p, e q p} / \widetilde{x}_{e q p}=0.67$. However, equipment spending accounted for only a small share of total investment spending, namely, 27 percent. That is, $\widetilde{x}_{e q p} / \widetilde{x}=0.27$. Construction spending, therefore, made up the lion's share of spending on investment goods, namely, 73 percent. That is, $\widetilde{x}_{\text {con }} / \widetilde{x}=0.73$. And here, on construction spending, imports made up only a small share of spending. Imports of intermediates only made up 7 percent of construction spending. That is, $x_{i m p, i n t} / \widetilde{x}_{c o n}=0.07$. Imports did not necessarily have to make up such a small share of construction spending in Turkey. To see this, I write construction spending as

$$
\widetilde{x}_{c o n}=x_{i n t, c o n}+x_{i m p, i n t}+x_{c o n},
$$

where $x_{i n t, c o n}$ is the value of the intermediate goods produced in the manufacturing sector that are used in structures. So spending on construction equals the value of intermediate goods used in structures (both imported and domestically produced) plus the value added in making structures. The value of intermediate goods used in structures accounted for 43 
percent of construction spending. Most of the intermediate goods used in construction were produced in Turkey, namely, 83 percent.

Therefore, a big reason why domestic production was a large share of investment spending in Turkey was because construction was a large share of total spending and because domestic intermediate production made up a large share of construction spending. This import substitution in intermediates goods, then, accounted for domestic production being a large share of total spending. If Turkey had imported the intermediate goods used in construction, rather than producing most of them, then imports would have made up 50 percent of total investment spending, which is more than twice the actual total.

I can now turn to the question at hand: What is a reasonable value for $\lambda_{x}$ for a country like Egypt? If a reasonable value for the government's share of value added, $x^{g} / x$, is about 0.75, what about the government's share of inputs, $\lambda_{x}$ ? In the model, the government's share of value added is a function of $\lambda_{x}$; namely,

$$
\frac{x^{g}}{x}=\frac{\lambda_{x} \cdot \mu_{g}}{\lambda_{x} \cdot \mu_{g}+\left(1-\lambda_{x}\right) \cdot \mu_{p}}
$$

From this expression, I can solve for $\lambda_{x}$ as a function of $x^{g} / x$ and call it $\widetilde{\lambda}_{x}\left(x^{g} / x\right)$. The term $\tilde{\lambda}_{x}\left(x^{g} / x\right)$ is the input share associated with the output share $x^{g} / x$. Note that $\tilde{\lambda}_{x}\left(x^{g} / x\right)$ $>x^{g} / x$. This follows because the government is less efficient than the private sector. Hence, if the government accounts for 10 percent of output, this means it accounts for more than 10 percent of inputs. Hence, for Egypt, $\lambda_{x}$ exceeds 0.75 .

Productivity Parameters (that is, $\mu / \mu_{g}$ and $\mu / \mu_{p}$ )

Before discussing the productivity studies I use to calibrate the model, let me say a few words about why I expect an industry run by the government to be less efficient than a 
competitive industry. My view is that government industries are often monopoly industries and that monopoly leads to inefficiency. Admittedly, there are very few models that imply that introducing monopoly leads to large decreases in industry TFP (or, conversely, that introducing competition leads to large TFP gains). Some models that have this flavor are Holmes and Schmitz $(1995,1997)$ and Parente and Prescott (1997). In Holmes and Schmitz (1997), entrepreneurs within an industry divide their time between researching and blocking the progress of their rivals (for example, through lobbying for regulations). If competition from other locations is increased (for example, by a decrease in tariffs), then entrepreneurs spend more of their time researching. Thus, productivity increases. ${ }^{10}$ The models presented by Holmes and Schmitz and Parente and Prescott offer some reasons to expect $\mu>\mu_{g}$.

Suppose now that the government does not take over the entire industry, so there are private producers that remain. Because government is inefficient, it may place restrictions on private producers to limit their productivity. Otherwise, the productivity differences between private and government may be too large. Hence, there are reasons to expect private producers without government to be more productive than those with government production; that is, $\mu>\mu_{p}$. So there are some reasons to expect that $\mu>\mu_{p}>\mu_{g}$. What do studies show?

A number of studies compare investment-sector government and private TFP within a country. For example, Krueger and Tuncer (1982) study government and private TFP in Turkey's manufacturing sector. With Krueger and Tuncer's study, I am able to compute private TFP relative to government TFP in Turkey's intermediate goods and equipment

\footnotetext{
${ }^{10}$ While there is not a lot of theory for why monopoly is inefficient, a growing body of evidence suggests that competition spurs productivity. These empirical studies include Baily (1993), Baily and Gersbach (1995), and Nickell (1996).
} 
industries. These estimates are given in Table 3 for the years 1963 and 1976 . For the 15 industry-year pairs in the table, private TFP exceeded government in 12 of the 15 cases. On average, private TFP in these industries was 1.916 times that of government TFP in 1963; in 1976 , the multiple was $2.539 .{ }^{11}$

Table 3 also presents estimates for the same industries in Egypt for the years 1970 and 1980. These estimates are derived from Handoussa (1991). For the 10 industry-year pairs in the table, private TFP exceeded government in 8 of the 10 cases. On average, private TFP in these industries was 2.057 times that of government TFP in 1970; in 1980, the multiple was $2.224 .{ }^{12}$

The studies summarized in Table 3 suggest that a reasonable value for the ratio $\mu_{p} / \mu_{g}$ is 2 .

Some studies compare investment-sector government efficiency with that of private efficiency in other countries. One such study is Funkhouser and MacAvoy (1979), which sets out to compare government and private enterprises within Indonesia. However, for some industries in Indonesia, there were only government firms. Funkhouser and MacAvoy expand their study by surveying private firms in these industries in "adjoining Southeast Asian countries."

\footnotetext{
${ }^{11}$ These estimates are derived from Krueger and Tuncer (1982) as follows. With the Cobb-Douglas technology, the ratio of private to government TFP can be expressed as the product of two terms: the ratio of labor input per unit of output, government to private (the ratio raised to the power of labor's share in output) and the ratio of capital input per unit of output, government to private (the ratio raised to the power of capital's share in output). The terms in this product are found in Table 5 of Krueger and Tuncer.

${ }^{12}$ These estimates are derived as follows. With the Cobb-Douglas technology, the ratio of private to government TFP can be expressed as the ratio of two terms: private labor productivity divided by government labor productivity and private capital per worker (capital per worker raised to the power of capital's share in output) divided by government capital per worker (capital per worker raised to the power of capital's share in output). Labor productivity estimates are found in Handoussa (1991) in Table 32, and capital per worker estimates are found in Table 31. Since estimates of capital share are not reported, I use the estimates that are given in Krueger and Tuncer (1982) for each industry.
} 
The results of their study with regard to productivity are included in Table 4 . The table reports productivity for those industries in Funkhouser and MacAvoy's (1979) study that produced investment goods (intermediate goods and structures). The first column of Table 4 lists the labor productivity of private enterprises relative to government enterprises within Indonesia. Hence, Table 4 gives estimates of $\mu_{p} / \mu_{g}$. In all industries within Indonesia in Table 4, private production is more productive than government. The magnitude of the numbers is similar to that in Table 3.

The second column of Table 4 lists the productivity of private firms in countries adjoining Indonesia relative to government firms in Indonesia. Hence, Table 4 provides estimates of $\mu / \mu_{g}$. As one can see, the $\mu / \mu_{g}$ estimates in the second column are much bigger than the $\mu_{p} / \mu_{g}$ estimates in the first column. Suppose one focuses on the industries in Table 4 in which productivity is based on physical measures of output, that is, the first four industries in the table, and one does not focus on construction in which productivity is based on a sales measure of output. Then the estimates of $\mu_{p} / \mu_{g}$ are 2.558 and 2.660 , while those for $\mu / \mu_{g}$ are 6.024 and 4.329 .

There are a couple of caveats about the Funkhouser and MacAvoy (1979) estimates. One caveat is that the estimates are of relative labor productivity and not relative TFP. What would relative TFP estimates look like? The same question is, What type of enterprise (government or private) has more capital per worker? There are, of course, famous stories of overstaffing in government enterprises. However, on the other hand, government enterprises typically have access to credit on much cheaper terms than private enterprises have for purchasing capital. What are the facts? As Krueger and Tuncer (1982, p. 324) report, Turkish government enterprises are more capital intensive than their private counterparts. The same 
is true in Egypt. For Egypt's manufacturing sector, Handoussa (1991, p. 102, Table 31) reports that capital intensity in the government sector exceeded that in the private sector by a factor of 5 in 1970 and 2.5 in 1980. So the evidence I have seen suggests that government enterprises are more capital intensive than private ones. ${ }^{13}$

The other caveat is that for the private enterprises surveyed outside of Indonesia, Funkhouser and MacAvoy (1979) only report that the firms were in "adjoining Southeast Asian countries." They do not report the names of the countries. But from this description, I can reasonably assume that the countries were at similar levels of development as Indonesia. Also, since I do not have the names of the countries, I cannot check if the private enterprises outside of Indonesia operated in industries with some government production or not. I have been implicitly assuming that the private enterprises operated in industries without government (since I have taken the private enterprises' productivity to be $\mu$ ). However, I do know that if there is government production in the industry, then it makes up a smaller share than the government's share in Indonesia, where the government accounts for the entire industry.

What then does this study in Table 4 ultimately suggest as a reasonable value for the ratio $\mu / \mu_{g}$ ? I, of course, do not want to draw too much from one study. And most readers probably find the size of the estimates of 4 and 6 as very large. But the study does suggest to me that $\mu>\mu_{p}$. If we normalize $\mu_{g}=1$, so that $\mu_{p}=2$ based on Table 3 , I plan to consider values of $\mu \in[2,3]$.

\footnotetext{
${ }^{13}$ This is not too surprising if one considers the twin facts that larger manufacturing plants typically have greater capital per worker than smaller manufacturing plants and that public manufacturing plants are on average much bigger than private ones.
} 


\section{The Model's Estimates of Relative Aggregate Labor Productivity}

Based on this discussion of parameters, I now discuss what is a reasonable estimate for how government production of investment goods has influenced ALP in Egypt.

Table 5 presents the model's estimates of the impact of government production of investment goods on productivity. Table 5 compares the labor productivity of a country with no government production to a country where the government produces investment goods. Recall that relative ALP in this case is given by the expression in (14). It is a function of $\lambda_{x}$ (or $x^{g} / x$ ), $\mu / \mu_{g}$, and $\mu / \mu_{p}$. In Table 5 , I choose the normalization $\mu_{g}=1$. In panel A of Table $5, x^{g} / x=1$. In panel B of Table $5, x^{g} / x=0.75$. Entries in the matrices give values of relative ALP for various values of private TFP in the country with no government production, that is, $\mu$, and private TFP in the country with government production, that is, $\mu_{p}$.

In panel A of Table 5 , if $\mu=1.5$, then $z=1.31$. The value of $\mu_{p}$ of does not matter, of course, since $x^{g} / x=1$ so that there are no private producers in the country with government production. If $\mu=2$, then $z=1.57$. If $\mu=3$, then $z=2$.

In panel B of Table 5 , the first row of numbers is identical to the first row of numbers in panel $\mathrm{A}$. That is true because the first row of panel $\mathrm{B}$ is for $\mu_{p}=1$, which means that private producers in the country with government production have the same productivity as government producers (recall that $\mu_{g}=1$ ). If one reads down a column in panel $\mathrm{B}$, the productivity of private producers in the country with government production increases. Hence, the productivity of the country with no government production relative to the productivity of the country with government production decreases. For example, if $\mu=3$ and $\mu_{p}=1$, then $z=2$. If $\mu=3$ and $\mu_{p}=2$, then $z=1.85$. As one can see, the numbers do not fall dramatically as one reads down a column in panel B. 
So what is a reasonable estimate for how this policy has influenced productivity in Egypt? The term $x^{g} / x=0.75$ is a reasonable approximation for the government's share of investment output in Egypt. Table 3 suggests that $\mu_{p} / \mu_{g}$ is at least 2 , so with $\mu_{g}=1$, this implies $\mu_{p}=2$ is a conservative estimate. These parameters, therefore, place one in row 3 of panel B of Table 5. Now, as I mentioned, Table 4 suggests that there are reasons to consider a value of $\mu$ bigger than $\mu_{p}=2$. As $\mu$ varies between 2 and 3 in row 3 of panel $\mathrm{B}$ of Table 5, relative productivity varies between 1.45 and 1.85. As I mentioned in the introduction, ALP in the United States was about 8 times that of Egypt's during the 1960s (see Summers and Heston (1991)), a period when Egypt vigorously pursued this policy . What fraction of the ALP gap between the United States and Egypt does the model then attribute to this policy? In order to answer this question, I need some metric to measure the fraction of the gap explained by this policy.

In thinking about a metric, suppose I had identified three policies, each of which implied that the United States should be twice as productive as Egypt. Taken together, the policies would imply that the United States should be 8 times as productive as Egypt. Then identifying one policy of three means that I am one-third of the way to explaining the overall productivity difference. A metric that would imply this as the fraction of the gap is as follows. Change variables from $z$, the measure of relative ALP, to $v$ using the formula $z=2^{v}$. Then $v=\ln z / \ln 2$. Let $z_{m}$ and $z_{d}$ denote the relative ALP in the model and data, respectively (with $v_{m}$ and $v_{d}$ the associated $v^{\prime}$ 's). Measure the fraction of the gap by the ratio of the $v^{\prime}$; namely, $v_{m} / v_{d}=\left(\ln z_{m} / \ln 2\right) \div\left(\ln z_{d} / \ln 2\right)$. If $z_{m}=2$ and $z_{d}=8$, then $v_{m} / v_{d}=1 / 3$.

The metric above is equivalent to one in which the fraction of the gap explained is defined by taking the difference in the logarithms of ALP in the model (which, when one 
uses the normalization that $y_{U}=2$ and $y_{E}=1$, is $\ln z_{m}$ ) and dividing by the difference in the logarithms of ALP in the data (which, when one uses the normalization that $y_{U}=8$ and $y_{E}=1$, is $\left.\ln z_{d}\right)$.

Now that I have a metric, recall that as $\mu$ varies between 2 and 3 in row 3 , relative productivity varies between 1.45 and 1.85 . If I use the metric above, if $\mu=3$, then $\ln z_{m} \div \ln z_{d}=\ln (1.85) \div \ln 8 \simeq 0.30$ so that the policy accounts for about 30 percent of the productivity gap. I highlighted this calculation in the introduction when I argued that the policy accounts for about one-third of the productivity gap. If $\mu=2$, then $\ln z_{m} \div \ln z_{d}=\ln (1.45) \div$ $\ln 8 \simeq 0.18$ so that the policy accounts for about 18 percent of the productivity gap.

\section{Consumption Versus Investment}

In this section, I show that a government policy to produce consumption goods has a very different effect from one producing investment goods. This follows from the fact that increases in $\lambda_{x}$ decrease $k^{*}$ in (8), while increases in $\lambda_{c}$ do not.

Consider two contrasting policies, polices $a$ and $b$, defined by

$$
\text { policy } a: \lambda_{c}=\lambda / n_{c}^{*}, \quad \lambda_{x}=0 ; \quad \text { policy } b: \lambda_{c}=0, \quad \lambda_{x}=\lambda / n_{x}^{*}
$$

where $\lambda \in\left[0, n_{x}^{*}\right]$ and where $n_{x}^{*}$ and $n_{c}^{*}$ are the steady-state time allocations derived from $(7)$. I now say a few words about these policies. Recall that the steady-state time allocations are not functions of $\lambda_{c}$ and $\lambda_{x}$. Hence, the policies are well-defined. Because of the restriction on $\lambda$, both $\lambda_{c}$ in policy $a$ and $\lambda_{x}$ in policy $b$ are less than 1 (under the assumption that $n_{x}^{*}$ $\left.<n_{c}^{*}\right)$. Policy $a$ involves government production of consumption goods alone, while policy $b$ involves investment goods alone. Finally, both policies involve the government's use of the same fraction of inputs $\lambda$ in the steady state; that is, under policy $a$ and $b, \sum_{s} \lambda_{s} \cdot n_{s}^{*}=\lambda$. 
Let $z_{a}(\lambda)$ denote the aggregate productivity of a country with no government production relative to that of a country pursuing policy $a$. Define $z_{b}(\lambda)$ similarly. Both $z_{a}$ and $z_{b}$ exceed 1. I show that $z_{b}$ is much larger than $z_{a}$.

I have already calculated the formula $z_{b}(\lambda)$. That is, $z_{b}(\lambda)$ is found by setting $\lambda_{x}=$ $\lambda / n_{x}^{*}$ in formula (14) above. The term $z_{a}(\lambda)$ can be constructed by displaying formula (12) for the case when the Egyptian government only produces consumption goods. In this case, $m_{E c}\left(\lambda_{E_{c}}=\lambda_{c}\right)=\bar{\mu}_{c}$ and $m_{E x}\left(\lambda_{E x}=0\right)=\mu$. The expression for $z$ then becomes

$$
z_{a}(\lambda)=\left(1+\frac{1}{4} \cdot \frac{\mu}{\bar{\mu}_{c}}\right)^{-1} \cdot\left(\frac{\mu}{\bar{\mu}_{c}}\right)+\left[1-\left(1+\frac{1}{4} \cdot \frac{\mu}{\bar{\mu}_{c}}\right)^{-1}\right] \cdot 1
$$

where $\bar{\mu}_{c}=\lambda_{c} \mu_{g}+\left(1-\lambda_{c}\right) \mu_{p}$ and $\lambda_{c}=\lambda / n_{c}^{*}$ (note the investment-sector productivity is identical across countries).

Let me assume that $\lambda=0.20$. Hence, the government makes up the entire investment sector under policy $b$ and one-fourth of the consumption sector under policy $a$ (recall that $n_{x}^{*}$ $=0.20$ and $\left.n_{c}^{*}=0.80\right)$.

Values for $z_{b}$ can be found in panel A of Table 5 (where $\lambda_{x}=1$ ). For example, if $\mu=3$, then $z_{b}=2$.

Values for $z_{a}$ are calculated from expression (17) above. I maintain the assumption that $\lambda=0.20$ and $\mu=3$. I also specify a value for $\mu_{p}$. Since the government's share of output of the consumption goods is small (that is, one-fourth), and recalling expression (4) and the discussions surrounding it, I assume that the productivity of private producers is not influenced by government production. That is, I use $\mu_{p}=3$. Then $z_{a}=1.15$.

In summary, the policy of government production of investment goods leads to $z_{b}=2$, and the policy of government production of consumption goods leads to $z_{a}=1.15$. If relative 
ALP in the data is $z_{d}$, the fraction of the gap explained by the investment policy relative to the fraction of the gap explained by the consumption policy is $\left(\ln z_{b} / \ln z_{d}\right) \div\left(\ln z_{a} / \ln z_{d}\right) \simeq 5$. The policy of producing investment goods explains 5 times more of the gap than the consumptiongood policy.

In comparing the impact of the two policies, I should mention that the larger the value of $\mu_{p}$, the smaller is $z_{a}$. This is true for the same reason why the entries in panel B in Table 5 fall as one reads down a column. The value of $\mu_{p}$ does not make a big difference in panel B of Table 5. That is true because private producers in the country with government production make up a small share of investment-sector output. But in the government production of consumption-goods exercise, private producers make up the majority of the output. Hence, the value of $\mu_{p}$ makes a bigger difference in this case.

\section{Conclusion}

Not many papers explore the impact of specific policies on aggregate labor productivity. This is true not because economists think the issue is an unimportant one, rather because of the difficulty in conducting such exercises. In this paper, I estimated the impact of a policy whereby the government substitutes for private enterprise in producing investment goods. The estimates showed that the policy can have a large negative impact on aggregate labor productivity. The policy accounted for one-third of Egypt's aggregate labor productivity gap with the Untied States during the 1960s.

In the introduction, I mentioned the literature that discusses trade policies. My point was to emphasize the shared goal of that literature and this paper, which was to estimate the impact of policy on aggregate outcomes. Other connections do exist between the trade 
literature and this paper, less obvious perhaps, but connections worthy of further thought and study. Because government production is less efficient than private production, government production in countries is typically supported by tariffs or quotas on imports of the goods government produces. Hence, another cost of tariffs is the role of tariffs in protecting government production. The biggest impact of tariffs on aggregate outcomes may well be the tariff's support of inefficient production. 


\section{Appendix}

In the Appendix, I begin by constructing the expressions (5), (6), (7), (8), and (9). Then I briefly discuss other tax and subsidy schemes.

\section{A1. Steady-State Solution}

I start by assuming $\lambda_{s}$ is large. The necessary conditions for profit maximization, that each private and government enterprise set its marginal product of capital equal to $r$ and marginal product of labor to $w$, imply that the capital per effective unit of time in each enterprise and sector are equal and, hence, the two equal the aggregate capital per effective unit of time; that is,

$$
k_{s t}^{g} /\left[(1+g)^{t} n_{s t}^{g}\right]=k_{s t}^{p} /\left[(1+g)^{t} n_{s t}^{p}\right]=k_{t} /(1+g)^{t}=k^{*} .
$$

From this condition, it follows that the fraction of time devoted to a sector equals the fraction of capital stock devoted to that sector; that is, $n_{s}^{*}=k_{s}^{*} / k^{*}$.

Using these conditions and the government-input requirements, I write $x_{t}^{g}$ (expression (2)) in the steady state as

$$
x_{t}^{g}=(1+g)^{t} \cdot \mu_{g} \cdot A_{x} \cdot\left(k^{*}\right)^{\gamma} \cdot n_{x}^{g}=(1+g)^{t} \cdot \mu_{g} \cdot A_{x} \cdot\left(k^{*}\right)^{\gamma} \cdot \lambda_{x} \cdot \frac{k_{x}^{*}}{k^{*}},
$$

since $n_{x}^{g}=\lambda_{x} \cdot n_{x}^{*}=\lambda_{x} \cdot k_{x}^{*} / k^{*}$. Similarly,

$$
x_{t}^{p}=(1+g)^{t} \cdot \mu_{p} \cdot A_{x} \cdot\left(k^{*}\right)^{\gamma} \cdot n_{x}^{p}=(1+g)^{t} \cdot \mu_{p} \cdot A_{x} \cdot\left(k^{*}\right)^{\gamma} \cdot\left(1-\lambda_{x}\right) \cdot \frac{k_{x}^{*}}{k^{*}},
$$

since $n_{x}^{p}=\left(1-\lambda_{x}\right) \cdot n_{x}^{*}=\left(1-\lambda_{x}\right) \cdot k_{x}^{*} / k^{*}$. In summing these expressions, I get the expression in (5) evaluated at $\lambda_{x}$ large, and similarly for expression (6). 
Let me now turn to deriving steady-state solutions for $k_{x}^{*} / k^{*}$ and $k^{*}$ (given in expressions (7) and (8)). Consider the necessary conditions associated with profit maximization for the private enterprise in sector $s=x$. These conditions include that the private enterprise set its marginal product of capital equal to $r$ :

$$
\left(1-\tau_{x}\right) \cdot p_{x} \cdot \gamma \cdot \mu_{p} \cdot A_{x} \cdot\left(k_{x}^{p}\right)^{\gamma-1} \cdot\left((1+g)^{t} \cdot n_{x}^{p}\right)^{1-\gamma}=r .
$$

Using $k_{x t}^{p} /(1+g)^{t} \cdot n_{x t}^{p}=k^{*}$, I find that this equation gives $k^{*}$ as a function of the two values $\left(1-\tau_{x}^{*}\right)$ and $r^{*} / p_{x}^{*}$

The term $r^{*} / p_{x}^{*}$ can be calculated from the household's problem. A necessary condition for utility maximization is

$$
p_{x t} \cdot\left(c_{t}\right)^{-\theta}=\beta \cdot\left(c_{t+1}\right)^{-\theta} \cdot\left[r_{t+1}+p_{x, t+1} \cdot(1-\delta)\right]
$$

Using steady-state conditions $c_{t}=c^{*} \cdot(1+g)^{t}$ and $p_{x t}=p_{x, t+1}$, I have

$$
\frac{r^{*}}{p_{x}^{*}}=\frac{(1+g)^{\theta}}{\beta}-(1-\delta) .
$$

The term $\left(1-\tau_{x}^{*}\right)$ can be calculated from two necessary conditions. The first condition is that taxes equal subsidies; namely,

$$
\tau_{x} \cdot p_{x} \cdot x_{t}^{p}=\sigma_{x} \cdot p_{x} \cdot x_{t}^{g}
$$

Using the expressions for $x_{t}^{g}$ and $x_{t}^{p}$ above, I can write this condition as

$$
\frac{\tau_{x}}{\sigma_{x}}=\frac{\lambda_{x} \cdot \mu_{g}}{\left(1-\lambda_{x}\right) \cdot \mu_{p}} .
$$

Next, in order for both firms in the $x$ sector to produce, and that there be market clearing, it must be that

$$
\left(1-\tau_{x}\right) \cdot \mu_{p}=\left(1+\sigma_{x}\right) \cdot \mu_{g}
$$


Solving these last two equations above, I get $\sigma_{x}^{*}$ and $\tau_{x}^{*}$, and it is easy to show that $\left(1-\tau_{x}^{*}\right)$. $\mu_{p}=\bar{\mu}_{x}=\left(\lambda_{x} \cdot \mu_{g}+\left(1-\lambda_{x}\right) \cdot \mu_{p}\right)$.

Substituting these expression for $\left(1-\tau_{x}^{*}\right) \cdot \mu_{p}$ and $r^{*} / p_{x}^{*}$ into equation (18), I can solve for $k^{*}$ as a function of $\bar{\mu}_{x}$, which is the expression given in equation (8) in the text evaluated at $\lambda_{x}$ large.

Next let me calculate $k_{x}^{*} / k^{*}$. Take the expression in (5) for $x_{t}$ and the steady-state condition $k_{t}=k^{*} \cdot(1+g)^{t}$. Substitute both into the law of motion for capital, $k_{t+1}=$ $(1-\delta) \cdot k_{t}+x_{t}$, and rearrange the expression to yield equation (7) in the text.

Consider next the steady-state price $p_{x}^{*}$. A necessary condition for both the private $x$-sector and $c$-sector firms to produce, and there be market clearing, is that

$$
\left(1-\tau_{x}\right) \cdot p_{x} \cdot \mu_{p} \cdot A_{x}=\left(1-\tau_{c}\right) \cdot \mu_{p} \cdot A_{c}
$$

Using $\left(1-\tau_{s}^{*}\right) \cdot \mu_{p}=\bar{\mu}_{s}=\left(\lambda_{s} \cdot \mu_{g}+\left(1-\lambda_{s}\right) \cdot \mu_{p}\right)$, I can solve this equation for $p_{x}$ as a function of $\bar{\mu}_{c}$ and $\bar{\mu}_{x}$, which is the expression (9) given in the text evaluated at $\lambda_{s}$ large.

Next suppose that $\lambda_{s}=0$. In this case, $\sigma_{s}^{*}=\tau_{s}^{*}=0$. To calculate the steady state in this case, the technologies in equation (1) are used. One can show that the steady-state paths for $c_{t}, x_{t}$, and $p_{x t}$ in this case are given by the expressions (5), (6), (7), (8), and (9) evaluated at $\lambda_{s}=0$.

Let me now consider how other tax and subsidy schemes would change the steadystate paths given in (5), (6), (7), (8), and (9). Note that in deriving expressions (5) and (6) above, I did not use any details of the tax and subsidy scheme. Expressions (5) and (6) do not depend on the scheme. The other expressions do depend on the particular scheme. Let me discuss a few other schemes. 
One scheme is to tax the private firm in the investment sector (and not subsidize the government enterprise) and return these taxes lump sum to households. In order for a steady state with both government and private production to exist, the tax rate $\tau_{x}$ must be set so that $\left(1-\tau_{x}\right) \cdot \mu_{p}=\mu_{g}$. Examining equation (18), one sees that $k^{*}$ in this case can be found by substituting $\mu_{g}$ for $\bar{\mu}_{x}$ in expression (8) when $\lambda_{x}$ is large. Under this scheme, increases in government production of investment goods lead to a greater decrease in aggregate productivity as compared to the scheme in the text.

Another scheme is to subsidize government production in investment goods (and not tax private production) and tax households lump sum to pay for it. In order for a steady state with both government and private production to exist, the subsidy rate $\sigma_{x}$ must be set so that $\left(1+\sigma_{x}\right) \cdot \mu_{g}=\mu_{p}$. In this case, $k^{*}$ is found by substituting $\mu_{p}$ for $\bar{\mu}_{x}$ in expression (8) when $\lambda_{x}$ is large. Under this scheme, increases in government production of investment goods lead to a smaller decrease in aggregate productivity as compared to the scheme in the text.

Is the decrease in productivity very different across these three financing schemes? The differences depend in large part on how different $\mu_{g}$ and $\mu_{p}$ are from each other. If they are a similar magnitude, then the differences are small.

Another type of scheme would be to subsidize public firms and raise revenues for the subsidies by taxing earnings on capital rentals. In this case, the tax on capital earnings would change the household's budget constraint. The equilibrium interest rate would also change. This type of scheme may lead to the biggest decrease in productivity. 


\section{References}

Baily, Martin Neil. "Competition, Regulation, and Efficiency in Service Industries," Brookings Papers on Economic Activity, Microeconomics 1993, 71-130.

Baily, Martin Neil, and Gersbach, Hans. "Efficiency in Manufacturing and the Need for Global Competition," Brookings Papers on Economic Activity, Microeconomics 1995, $307-47$.

Chari, V.V.; Kehoe, Patrick J.; and McGrattan, Ellen R. "The Poverty of Nations: A Quantitative Exploration," Research Department Staff Report 204, Federal Reserve Bank of Minneapolis, 1997.

Funkhouser, Richard, and MacAvoy, Paul W. "A Sample of Observations on Comparative Prices in Public and Private Enterprises," Journal of Public Economics 11(3), 1979, $353-68$.

Handoussa, Heba. "Reform Policies for Egypt's Manufacturing Sector," in Employment and Structural Adjustment: Egypt in the 1990s, pp. 95-123. Edited by Heba Handoussa and Gillian Potter. Cairo, Egypt: American University in Cairo Press, 1991.

Hansen, Bent, and Nashashibi, Karim. Egypt. New York: National Bureau of Economic Research, 1975.

Holmes, Thomas J., and Schmitz, James A., Jr. "Resistance to New Technology and Trade Between Areas," Federal Reserve Bank of Minneapolis Quarterly Review 19 (Winter), $1995,2-17$.

Holmes, Thomas J., and Schmitz, James A., Jr. "Competition and Trade as Spurs to Productivity," Manuscript, Federal Reserve Bank of Minneapolis, 1997. 
Industry of Free China, various issues.

Klenow, Peter J., and Rodríguez-Clare, Andrés. "Quantifying Variety Gains from Trade Liberalization," Working Paper, Graduate School of Business, University of Chicago, 1996.

Krueger, Anne O. Turkey. Foreign Trade Regimes and Economic Development, Vol. 1. New York: National Bureau of Economic Research, 1974.

Krueger, Anne O., and Tuncer, Baran. "Growth of Factor Productivity in Turkish Manufacturing Industries," Journal of Development Economics 11(3), 1982, 307-25.

Lucas, Robert E., Jr. "On the Mechanics of Economic Development," Journal of Monetary Economics 22(1), 1988, 3-42.

Mabro, Robert, and Radwan, Samir. The Industrialization of Egypt, 1939-1973: Policy and Performance. Oxford: Clarendon Press, 1976.

Mankiw, N. Gregory; Romer, David; and Weil, David N. "A Contribution to the Empirics of Economic Growth," Quarterly Journal of Economics 107(2), 1992, 407-37.

Nickell, Stephen J., "Competition and Corporate Performance," Journal of Political Economy 104(4), 1996, 724-46.

Parente, Stephen L., and Prescott, Edward C. "Barriers to Technology Adoption and Development," Journal of Political Economy 102(2), 1994, 298-321.

Parente, Stephen L., and Prescott, Edward C. "Monopoly Rights: A Barrier to Riches," Research Department Staff Report 236, Federal Reserve Bank of Minneapolis, 1997.

Restuccia, Diego, and Urrutia, Carlos. "Public Policy, Price Distortions, and Investment Rates," Working Paper, University of Minnesota, 1996.

Rodríguez-Clare, Andrés. "The Role of Trade in Technology Diffusion," Institute of Em- 
pirical Macroeconomics Discussion Paper 114, Federal Reserve Bank of Minneapolis, 1996.

Schmitz, James A., Jr. "The Role Played by Public Enterprises: How Much Does it Differ Across Countries?" Federal Reserve Bank of Minneapolis Quarterly Review 20 (Spring), 1996, 2-15.

Srinivasan, T. N. "Comment on 'Two Strategies for Economic Development: Using Ideas and Producing Ideas,' by Paul Romer," in Proceedings of the World Bank Annual Conference on Development Economics 1992: Supplement to the World Bank Economic Review and The World Bank Research Observer. Washington, D.C.: World Bank, 1993, 103-09.

Summers, Robert, and Heston, Alan. "The Penn World Table (Mark 5): An Expanded Set of International Comparisons, 1950-1988," Quarterly Journal of Economics 106(2), 1991, 327-68.

Walstedt, Bertil. State Manufacturing Enterprise in a Mixed Economy: The Turkish Case. Baltimore: Published for the World Bank by the Johns Hopkins University Press, 1980. Waterbury, John. Exposed to Innumerable Delusions: Public Enterprise and State Power in Egypt, India, Mexico, and Turkey. Cambridge, England: Cambridge University Press, 1993.

World Bank. Bureaucrats in Business: The Economics and Politics of Government Ownership. New York: Oxford University Press, 1995. 
Table 1

Government Share of Manufacturing Output

Intermediate and Capital-Goods Industries

\begin{tabular}{|c|c|c|c|c|c|c|}
\hline \multirow[b]{2}{*}{ Industry } & \multicolumn{2}{|c|}{ Egypt (1966-67) } & \multicolumn{2}{|c|}{ Taiwan (1954) } & \multicolumn{2}{|c|}{ Turkey (1968) } \\
\hline & $\begin{array}{l}\text { Government } \\
\text { Share of } \\
\text { Industry } \\
\text { Output }\end{array}$ & $\begin{array}{c}\text { Industry } \\
\text { Share of } \\
\text { Manufacturing }\end{array}$ & $\begin{array}{l}\text { Government } \\
\text { Share of } \\
\text { Industry } \\
\text { Output }\end{array}$ & $\begin{array}{c}\text { Industry } \\
\text { Share of } \\
\text { Manufacturing }\end{array}$ & $\begin{array}{l}\text { Government } \\
\text { Share of } \\
\text { Industry } \\
\text { Output }\end{array}$ & $\begin{array}{c}\text { Industry } \\
\text { Share of } \\
\text { Manufacturing }\end{array}$ \\
\hline Chemicals & 94.0 & 10.8 & 62.8 & 8.6 & 16.8 & 5.1 \\
\hline Petroleum & 100.0 & 4.4 & 93.2 & 5.1 & 98.1 & 11.9 \\
\hline $\begin{array}{l}\text { Nonmetallic } \\
\text { minerals }\end{array}$ & 65.0 & 4.3 & 0.0 & 4.6 & 30.6 & 5.2 \\
\hline Basic metals & 94.0 & 3.4 & 55.2 & 4.1 & 88.2 & 9.8 \\
\hline Metal products & 51.0 & 4.3 & 65.0 & 1.4 & 45.7 & 2.9 \\
\hline Machinery & 75.0 & 1.1 & 43.2 & 0.9 & 14.9 & 2.6 \\
\hline $\begin{array}{l}\text { Electrical } \\
\text { equipment }\end{array}$ & 90.0 & 3.0 & 0.0 & 0.9 & 1.9 & 1.9 \\
\hline $\begin{array}{l}\text { Transport } \\
\text { equipment }\end{array}$ & 59.0 & 2.7 & 36.6 & 0.5 & 50.0 & 3.5 \\
\hline Weighted Average & 81.9 & & 40.7 & & 61.2 & \\
\hline
\end{tabular}

Sources: Egypt-Mabro and Radwan (1976); Taiwan-Industry of Free China; Turkey—Walstedt (1980). 
Table 2

Domestic Production and Imports of Investment Goods

As Share of Investment Spending

\begin{tabular}{lccc}
\hline \hline & $\begin{array}{c}\text { Egypt } \\
(1966-67)\end{array}$ & & $\begin{array}{c}\text { Turkey } \\
(1958)\end{array}$ \\
\cline { 2 - 2 } & $\begin{array}{c}\text { Percent } \\
\text { of } \\
\text { Investment } \\
\text { Spending }\end{array}$ & & $\begin{array}{c}\text { Percent } \\
\text { of } \\
\text { Investment } \\
\text { Spending }\end{array}$ \\
\hline Domestic Production & 80.0 & 77.0 \\
Imports & & \\
\multicolumn{2}{c}{$\begin{array}{l}\text { Intermediate Goods } \\
\text { Capital Goods }\end{array}$} & - & \\
\hline \hline
\end{tabular}

Sources: Egypt—Hansen and Nashashibi (1975); Turkey—Krueger (1974).

A dash (一) denotes not available. 
Table 3

Private TFP Relative to Government TFP

Intermediate and Capital-Goods Industries

\begin{tabular}{lcccccc}
\hline \hline & \multicolumn{2}{c}{ Egypt } & & \multicolumn{2}{c}{ Turkey } \\
\cline { 2 - 3 } \cline { 5 - 6 } Industry & 1970 & 1980 & & & 1963 & 1976 \\
\hline Chemicals & 1.534 & 2.237 & & 2.519 & 1.965 \\
Petroleum & - & - & & & 1.183 \\
Nonmetallic Mineral Products & 2.008 & 4.255 & & & .873 & 1.171 \\
Basic Metal Products & - & - & & 1.342 & 3.774 \\
Metal Products & 1.229 & 1.684 & & 2.703 & 3.021 \\
Machinery & 4.525 & 2.193 & & .596 & .920 \\
Electrical Machinery & .991 & .749 & & 1.953 & 4.651 \\
Transport Equipment & - & - & & 3.425 & 3.623 \\
& & & & & \\
Average & 2.057 & 2.224 & & & & \\
\hline \hline
\end{tabular}

Sources: Egypt—Handoussa (1991); Turkey—Krueger and Tuncer (1980).

A dash (-) means not available. 
Table 4

Private Labor Productivity Relative to Government Labor Productivity

In Various Investment-Good Industries

\begin{tabular}{|c|c|c|c|}
\hline \multirow[b]{2}{*}{ Industry } & \multirow[b]{2}{*}{ Output Measure } & \multicolumn{2}{|c|}{$\begin{array}{c}\text { Relative } \\
\text { Labor Productivity: }\end{array}$} \\
\hline & & $\begin{array}{c}\text { Private (Indonesia) } \\
\text { to } \\
\text { Government (Indonesia) }\end{array}$ & $\begin{array}{l}\text { Private (In Countries } \\
\text { Adjoining Indonesia) } \\
\text { to } \\
\text { Government (Indonesia) }\end{array}$ \\
\hline Rubber & Physical & 2.558 & \\
\hline Palm Oil & Physical & 2.660 & \\
\hline Cement & Physical & & 6.024 \\
\hline Fertilizer & Physical & & 4.329 \\
\hline Construction & Sales & & \\
\hline Contractors & & 1.057 & \\
\hline Engineers & & 1.176 & \\
\hline Architects & & 2.252 & \\
\hline
\end{tabular}

Source: Funkhouser and MacAvoy (1979). 
Table 5

Relative Aggregate Labor Productivity:

Labor Productivity of Country With No Government Production of Investment Goods

Divided by

Labor Productivity of Countries With Various Government Shares of Investment-Goods Output

Private TFP

(In Country With

Government

Production)

A. Government Share of Investment-Goods Output =

1.00

Private TFP

(In Country With No Government Production)

\begin{tabular}{|c|c|c|c|c|c|c|}
\hline & 1 & 1.5 & 2 & 2.5 & 3 & 4 \\
\hline 1 & 1 & 1.31 & 1.57 & 1.80 & 2.00 & 2.35 \\
\hline
\end{tabular}

B. Government Share of Investment-Goods Output $=.75$

Private TFP

(In Country With No Government Production)

Private TFP

(In Country With

Government

Production)

\begin{tabular}{|c|c|c|c|c|c|c|}
\hline & & (In & y Wit & $\begin{array}{l}\text { e TFP } \\
\text { Goverr }\end{array}$ & Produ & \\
\hline & 1 & 1.5 & 2 & 2.5 & 3 & 4 \\
\hline 1 & 1 & 1.31 & 1.57 & 1.80 & 2.00 & 2.35 \\
\hline 1.5 & & 1.24 & 1.49 & 1.71 & 1.90 & 2.24 \\
\hline 2 & & & 1.45 & 1.66 & 1.85 & 2.18 \\
\hline 2.5 & & & & 1.63 & 1.82 & 2.15 \\
\hline 3 & & & & & 1.80 & 2.12 \\
\hline 4 & & & & & & 2.09 \\
\hline
\end{tabular}

